\title{
Article \\ Slightly Acidic Electrolyzed Water to Remove Methylobacterium mesophilicum, Rhodotorula mucilaginosa and Cladosporium cladosporioides in Households
}

\author{
Angelica Naka $^{1, *(D)}$, Kenji Nakamura ${ }^{2}$ and Midori Kurahashi ${ }^{1}$ \\ 1 Graduate School of Agricultural and Life Sciences, The University of Tokyo, Tokyo 113-0032, Japan; \\ utkura@mail.ecc.u-tokyo.ac.jp \\ 2 Research Department, Toyotomi Co. Ltd., Nagoya 467-0855, Japan; kenji.n@toyotomi.jp \\ * Correspondence: angelica.naka@mail.ecc.u-tokyo.ac.jp
}

\section{check for} updates

Citation: Naka, A.; Nakamura, K.; Kurahashi, M. Slightly Acidic Electrolyzed Water to Remove Methylobacterium mesophilicum, Rhodotorula mucilaginosa and Cladosporium cladosporioides in Households. Appl. Microbiol. 2021, 1, 607-614. https://doi.org/10.3390/ applmicrobiol1030039

Academic Editor: Maria do Pilar de Araújo Teixeira

Received: 24 October 2021

Accepted: 10 December 2021

Published: 13 December 2021

Publisher's Note: MDPI stays neutral with regard to jurisdictional claims in published maps and institutional affiliations.

Copyright: (c) 2021 by the authors. Licensee MDPI, Basel, Switzerland. This article is an open access article distributed under the terms and conditions of the Creative Commons Attribution (CC BY) license (https:/ / creativecommons.org/licenses/by/ $4.0 /)$.

\begin{abstract}
Background: Slightly acidic electrolyzed water (SAEW) is an effective and safe sterilizing solution. Its active component is hypochlorous acid $(\mathrm{HOCl})$ which has been proved to exhibit a strong disinfectant activity. In this research we evaluated the effectiveness of SAEW in the removal of Methylobacterium mesophilicum, Rhodotorula mucilaginosa and Cladosporium cladosporioides, responsible for pink-colored biofilm and black mold in households. (2) Methods: Two concentrations of SAEW, $20 \mathrm{mg} / \mathrm{L}$ and $40 \mathrm{mg} / \mathrm{L}$, were tested against M. mesophilicum, R. mucilaginosa and C. cladosporioides. In vitro experiments and mesh experiments were conducted to test the effectiveness of SAEW. (3) Results: The test results showed that $40 \mathrm{mg} / \mathrm{L}$ SAEW was effective in removing $R$. mucilaginosa and C. cladosporioides, with the population decreasing by approximately two orders of magnitude. For M. mesophilicum, resistance towards SAEW was observed; to obtain a 1.3 order of magnitude decrease in bacterial population, washing 5 times with $40 \mathrm{mg} / \mathrm{L}$ SAEW was necessary. Mesh experiments showed that SAEW can remove black mold; (4) Conclusions: Overall results indicated that SAEW was particularly effective for R. mucilaginosa and C. cladosporioides species commonly found in Japanese households.
\end{abstract}

Keywords: slightly acidic electrolyzed water; Methylobacterium mesophilicum; Rhodotorula mucilaginosa; Cladosporium cladosporioides

\section{Introduction}

In 2020, the world was dedicated to the control and treatment of the severe acute respiratory syndrome coronavirus 2 (SARS-CoV-2) pandemic. Therefore, existing disinfectants were re-evaluated in each country, including hypochlorous acid water, which is known for its effectiveness, safety, and easy availability [1]. Hypochlorous acid $(\mathrm{HOCl})$ has extremely high bactericidal activity per molecule and is also produced by white blood cells within the human body to fight infections [2]. Hypochlorous acid is generally used for sanitation purposes in industries such as food production in concentrations ranging between 50 and $200 \mathrm{mg} / \mathrm{L}$ [3]. Water containing an extremely low concentration of $\mathrm{HOCl}$ can be considered an effective sterilizing agent while guaranteeing safety. However, under the hypochlorous acid water umbrella, there are a great number of products that differ in manufacturing method and stability. As such, they should not be considered as a single product [4]. For this study, we paid attention to a type called slightly acidic electrolyzed water (SAEW).

The SAEW developed in Japan is sterilized water containing $\mathrm{HOCl}$ as the main component. It is produced by electrolyzing aqueous solutions of $\mathrm{NaCl}$ or $\mathrm{KCl}$, or dilute hydrochloric acid water, in a non-diaphragm electrolytic cell at a low voltage (2V). The electrolyzed water generated in the electrolytic cell shows strong acidity. However, when diluted about 3000 times with tap water, the $\mathrm{pH}$ is adjusted to 5 to 6.5 by tap water's buffering capacity. Due to the simplicity of production, mechanical failures are rare and maintenance is easy. In addition, this system produces a stable and ready-to-use 
hypochlorous acid water while maintaining a low $\mathrm{HOCl}$ concentration. The preceding factors guarantee bactericidal efficacy, human safety and low environmental load. In Japan, the Ministry of Health, Labor and Welfare (2002), the Ministry of Agriculture, Forestry and Fisheries (2014), and the Ministry of the Environment (2014) have approved the use of these products with limited uses and concentrations [5]. In Japan, the current maximum allowed concentration of free chlorine in SAEW is $80 \mathrm{mg} / \mathrm{L}$. Furthermore, the Ministry of Health, Labor and Welfare of Japan (2021) has approved HOCl with extremely low concentrations (such as SAEW) for aerosol use.

SAEW is considered to be one of the few sterilizing aqueous solutions that can be sprayed into the air to eliminate airborne bacteria [6-8]. In our previous research, we sprayed bacteria in a clean booth and then sprayed SAEW in the same space to investigate the bactericidal effect $[5,9]$. SAEW, considered to be highly safe, is also suitable for household use. In this study, we investigated the disinfectant effect of SAEW against microorganisms that are frequently encountered in houses, especially bathrooms and drains in kitchens. Due to the SARS-CoV-2 pandemic, remote working has increased worldwide. In that context, effective hygiene and maintaining a good indoor environment are crucial. This may also help prevent respiratory problems such as asthma and rhinitis caused by molds [10-12].

The fungus most frequently present in houses is Cladosporium spp. [10,12-15]. Additionally, pink-colored contamination or biofilms often result from the growth of Rhodotorula spp. and/or Gram-negative bacteria Methylobacterium spp. [16]. Several methods and chemicals have been developed to help prevent or remove them. To our best knowledge, there is no research on the efficacy of SAEW or low $\mathrm{HOCl}$ concentration water in removing pink-colored biofilm and black mold. Therefore, there is a need to evaluate its potential use for their prevention or removal and determine the necessary concentration. Thus, the objectives of this study were to quantify the efficiency of SAEW in preventing Methylobacterium mesophilicum, Rhodotorula mucilaginosa and Cladosporium cladosporioides from spreading when directly applied. Furthermore, mesh impregnated with black mold was tested to evaluate SAEW's potential as a mold removal agent.

\section{Materials and Methods}

\subsection{Slightly Acidic Electrolyzed Water Generation}

SAEW was generated by electrolysis of a mixture of an aqueous dilute solution of $\mathrm{HCl}$ and tap water. Two different generators, an Apia 60 and Apia 270 (Hokuetsu Co. Ltd., Kanagawa, Japan), were used. The Apia 60 requires a 3\% $\mathrm{HCl}$ solution and produces approximately $20 \mathrm{mg} / \mathrm{L}$ of free chlorine, while the Apia 270 requires a $9 \% \mathrm{HCl}$ solution and generates approximately $40 \mathrm{mg} / \mathrm{L}$ of free chlorine. The physicochemical properties of SAEW were measured before each experiment. The $\mathrm{pH}$ was measured using the HI1280 Piccolo pH meter (Hanna Instruments Inc., Nusfalau, Romania). The free chlorine concentration was determined using the HI96771 Free Chlorine Photometer (Hanna Instruments Inc., Nusfalau, Romania).

\subsection{Culture Preparation}

Liquid-dried cultures of Methylobacterium mesophilicum (NBRC 15688), Rhodotorula mucilaginosa (NBRC 0909) and Cladosporium cladosporioides (NBRC 6368) were obtained from the Biological Resource Center (NBRC) of the National Institute of Technology and Evaluation (NITE), Japan. Microorganisms were revived according to the L-dried specimen reactivation method provided by the NBRC: The L-dried specimen ampoule was aseptically cut, a few drops of rehydration fluid $(0.9 \% \mathrm{NaCl}$ solution) were added and gently mixed for approx. $2 \mathrm{~min}$. The suspension was placed in agar plates and incubated the temperature specified by the NBRC until colonies were visually detected (stock).

Each specimen required a different agar medium. M. mesophilicum medium consisted of $10 \mathrm{~g}$ of hypolypepton (Nihon Pharmaceutical Co., Ltd., Tokyo, Japan), $2 \mathrm{~g}$ of yeast extract B2 (Oriental Yeast, Co., Ltd., Tokyo, Japan), 1 g of magnesium sulphate heptahydrate 
$\left(\mathrm{MgSO}_{4} \cdot 7 \mathrm{H}_{2} \mathrm{O}\right.$, Nacalai Tesque, Inc., Kyoto, Japan), and $15 \mathrm{~g}$ of agar powder (Wako Pure Chemical Industries Ltd., Osaka, Japan) in $1 \mathrm{~L}$ of distilled water. After autoclave sterilization of the medium, it was left undisturbed to allow the temperature to decrease to around $60{ }^{\circ} \mathrm{C}$. Then, $5 \mathrm{~mL}$ of methanol $99.8 \%$ (Kanto Chemical Co., Inc., Tokyo, Japan) sterilized by filtration was added. R. mucilaginosa medium consisted of $10 \mathrm{~g}$ of D-(+)-glucose (Hayashi Pure Chemical Ind., Ltd., Osaka, Japan), $5 \mathrm{~g}$ of peptone from glycine max (soybean) type IV, powder (Sigma-Aldrich, Missouri, United States), 3 g yeast extract B2 (Oriental Yeast, Co., Ltd., Tokyo, Japan), 3 g of bacto malt extract (Difco Laboratories, Maryland, United States), and $15 \mathrm{~mL}$ of agar powder (Wako Pure Chemical Industries Ltd., Osaka, Japan), in $1 \mathrm{~L}$ of distilled water. C. cladosporioides medium consisted of $39 \mathrm{~g}$ of potato dextrose agar "Nissui" (Nissui Pharmaceutical Co., Ltd., Tokyo, Japan) in $1 \mathrm{~L}$ of distilled water.

\subsection{In Vitro Experiments}

Cell culture was prepared to conduct experiments by transferring several colonies from the stock to $1 \mathrm{~mL}$ of $0.9 \% \mathrm{NaCl}$ solution using a sterile inoculation loop (Kenis Limited, Osaka, Japan) and shaking using a vortex mixer (Vortex-Genie 2, Scientific Industries Inc., New York, United States). We used the USHIO photo absorbance sensor PAS-110 (Ushio Inc., Tokyo, Japan) to make sure the absorbance of this solution was between 0.1 and 0.15 . From this solution, 7 series of 10 -fold dilutions were prepared by adding $100 \mu \mathrm{L}$ of the specimen suspension to $900 \mu \mathrm{L}$ of $0.9 \% \mathrm{NaCl}$ solution shaken using a vortex mixer. Thirty microliters of every solution were placed in agar plates and left undisturbed for $30 \mathrm{~min}$. After that, $5 \mathrm{~mL}$ (for R. mucilaginosa and C. cladosporioides) or $10 \mathrm{~mL}$ (for M. mesophilicum) of SAEW $20 \mathrm{mg} / \mathrm{L}$ and $40 \mathrm{mg} / \mathrm{L}$ was poured into each plate and left for $3 \mathrm{~min}$ before discarding the supernatant. Control was prepared by pouring the same amount of sterilized distilled water in the agar plate and discarding the supernatant after $3 \mathrm{~min}$. The plates were incubated at $28^{\circ} \mathrm{C}$ for 3 days for $R$. mucilaginosa, 3 to 5 days for $C$. cladosporioides, and 6 days for M. mesophilicum. After this period, the bacterial colony was counted and the bactericidal activity of SAEW determined. Microbial counts were expressed as $\log _{10} \mathrm{CFU} / \mathrm{mL}$, with the reduction in bacterial population also calculated and presented as $\log _{10} \mathrm{CFU} / \mathrm{mL}$. Each experimental case was replicated at least 6 times to ensure repeatability. Figure 1A shows the general procedure for in vitro experiments.

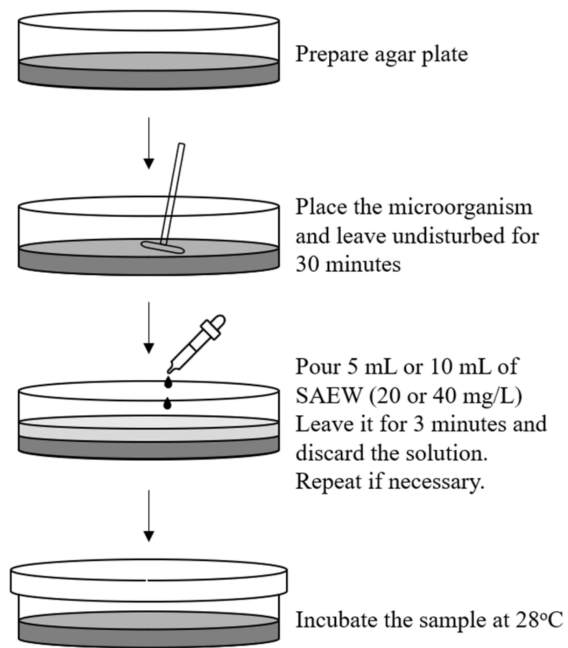

B

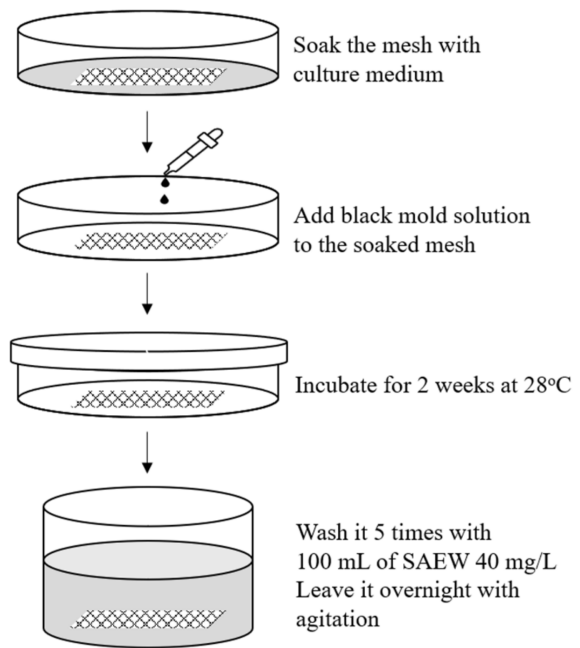

Figure 1. Schematic overview of (A) in-vitro and (B) mesh experiments.

\subsection{Mesh Experiment}

SAEW is potentially an effective way to remove black mold. Experiments were conducted by submerging and agitating mesh impregnated with black mold into SAEW. The mesh (polyester mesh) was first soaked in a black mold medium and placed in a Petri dish. Five hundred microliters of C. cladosporioides of $5.58 \log _{10} \mathrm{CFU} / \mathrm{mL}$ was placed on 
the whole area of the mesh. It was incubated for 2 weeks and then placed in a $250 \mathrm{~mL}$ flask with $100 \mathrm{~mL} \mathrm{SAEW} \mathrm{at} \mathrm{either} 20 \mathrm{mg} / \mathrm{L}$ or $40 \mathrm{mg} / \mathrm{L}$ concentrations. It was agitated at $200 \mathrm{rpm}$ for $5 \mathrm{~min}$, then the solution was discarded and replaced by new SAEW solution. This procedure was repeated 5 times, and the SAEW solution poured in the fifth time was left overnight. Distilled water was used as control. Five replications were performed for each case. Figure 1B presents a schematic overview of the mesh experiment.

\section{Results}

The $\mathrm{pH}$ of stock solutions and the available chlorine concentration of sterilized distilled water and SAEW are presented in Table 1. SAEW had a $\mathrm{pH}$ value ranging between 5.7 and 6.1 and a free chlorine concentration of $20 \pm 1 \mathrm{mg} / \mathrm{L}$ and $42 \pm 2 \mathrm{mg} / \mathrm{L}$. For simplicity, we refer to both SAEW concentrations as SAEW $20 \mathrm{mg} / \mathrm{L}$ and SAEW $40 \mathrm{mg} / \mathrm{L}$, respectively.

Table 1. Physicochemical properties of distilled water SAEW.

\begin{tabular}{ccc}
\hline & Concentration (mg/L) & pH (-) \\
\hline Distilled water & - & $7.01 \pm 0.23$ \\
Apia 60 (SAEW 20) & $20 \pm 1$ & $5.71 \pm 0.18$ \\
Apia 270 (SAEW 40) & $42 \pm 2$ & $6.01 \pm 0.04$ \\
\hline
\end{tabular}

\subsection{Pink-Colored Biofilm}

Survival populations of Methylobacterium mesophilicum and Rhodotorula mucilaginosa are presented in Figures 2 and 3. For M. mesophilicum, the initial average concentration was $4.66 \log _{10} \mathrm{CFU} / \mathrm{mL}$. Water (control) did not affect bacterial growth, as the bacterial population was $4.58 \log _{10} \mathrm{CFU} / \mathrm{mL}$ after water treatment. When SAEW $20 \mathrm{mg} / \mathrm{L}$ was used, a small M. mesophilicum population reduction was observed (from $4.66 \log _{10} \mathrm{CFU} / \mathrm{mL}$ to $4.29 \log _{10} \mathrm{CFU} / \mathrm{mL}$ ). For SAEW $40 \mathrm{mg} / \mathrm{L}$, agar plates with bacteria were washed 1 and 5 times with $10 \mathrm{~mL}$ of SAEW $40 \mathrm{mg} / \mathrm{L}$ each time. The survival populations were $4.11 \log _{10} \mathrm{CFU} / \mathrm{mL}$ and $3.32 \log _{10} \mathrm{CFU} / \mathrm{mL}$ after washing 1 and 5 times with $10 \mathrm{~mL}$ of SAEW $40 \mathrm{mg} / \mathrm{L}$, respectively. The maximum population decrease was $1.34 \log _{10} \mathrm{CFU} / \mathrm{mL}$, observed after washing the plate 5 times with $10 \mathrm{~mL}$ of SAEW $40 \mathrm{mg} / \mathrm{L}$. This result may indicate that $M$. mesophilicum showed resistance towards SAEW. Thus, to assess SAEW's disinfectant effect against this particular bacterium, we needed to wash it several times. Hiraishi, et al. [17] observed a similar result and reported that the majority of Methylobacterium strains show chlorine resistance. Even though the mechanism is still unknown, this research team found that the chlorine resistance capacity was developed by adapting to chlorinated environments. On the other hand, Ihara, Sakamoto, Yoshida and Tsuchido [16] implied that pink-slime microorganisms such as Methylobacterium usually have carotenoid pigments (antioxidant substances) in their cells that are believed to play an important role in cellular resistance to treatments such as chlorine, detergents, desiccation and UV.

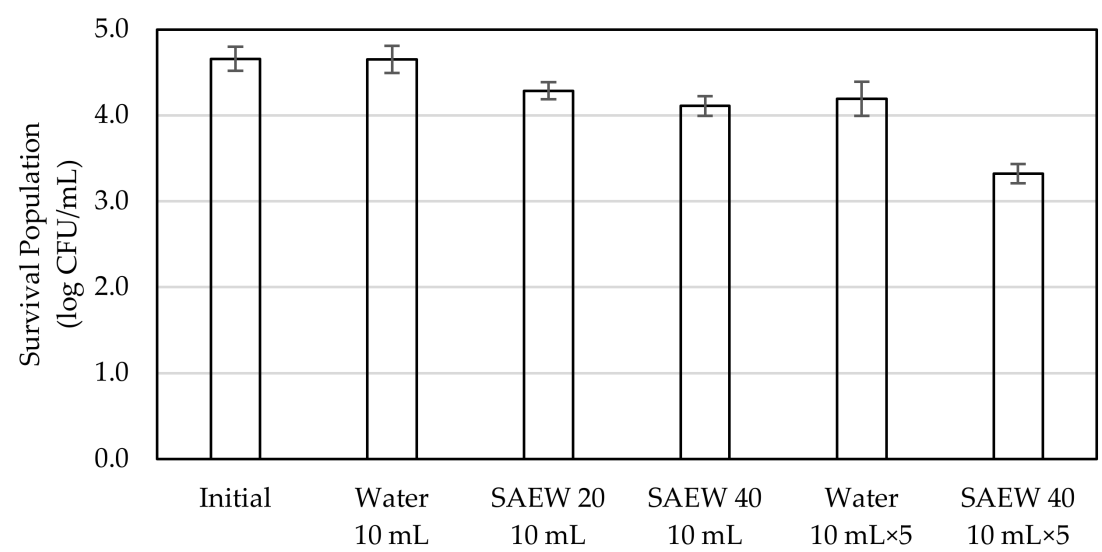

Figure 2. Survival population of Methylobacterium mesophilicum after SAEW treatment. 


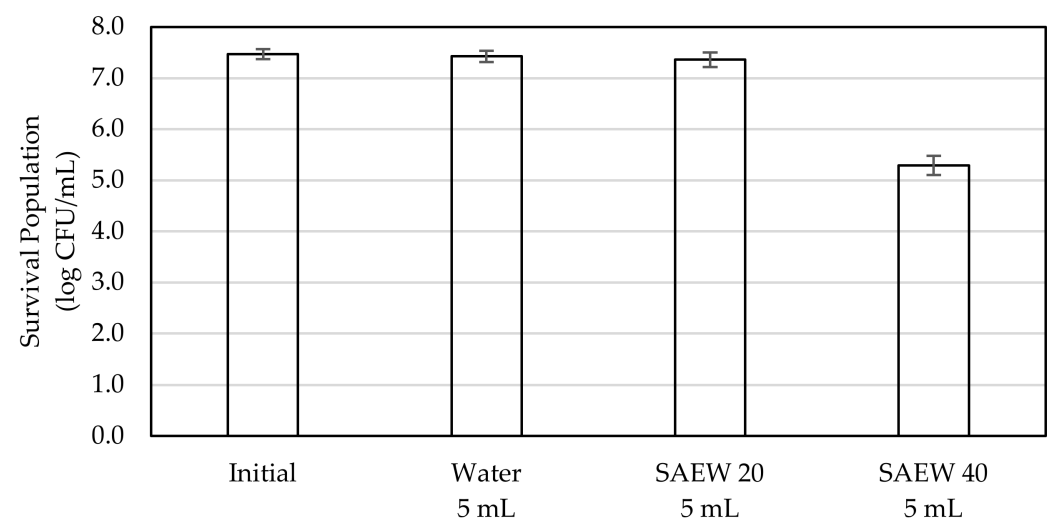

Figure 3. Survival population of Rhodotorula mucilaginosa after SAEW treatment.

For R. mucilaginosa, the initial average concentration was $7.47 \log _{10} \mathrm{CFU} / \mathrm{mL}$. After water treatment, the yeast concentration remained almost the same $\left(7.42 \log _{10} \mathrm{CFU} / \mathrm{mL}\right)$, which suggests that water did not affect $R$. mucilaginosa's growth. We observed that $5 \mathrm{~mL}$ of SAEW $20 \mathrm{mg} / \mathrm{L}$ was not very effective in removing this yeast. The yeast concentration was $7.36 \log _{10} \mathrm{CFU} / \mathrm{mL}$ after treatment with $20 \mathrm{mg} / \mathrm{L}$ of SAEW. However, a large decrease in the survival population of R. mucilaginosa was observed after washing the agar plate with $5 \mathrm{~mL}$ of SAEW $40 \mathrm{mg} / \mathrm{L}$. A decrease of more than 2 orders of magnitude $\left(2.07 \log _{10} \mathrm{CFU} / \mathrm{mL}\right)$ was observed in this case, which indicates that SAEW $40 \mathrm{mg} / \mathrm{L}$ might be effective in preventing the growth or spread of R. mucilaginosa, responsible for the majority of pinkcolored biofilms in households.

\subsection{Black Mold}

The survival population of Cladosporium cladosporioides is presented in Figure 4. The initial average concentration was $5.58 \log _{10} \mathrm{CFU} / \mathrm{mL}$. After water treatment (control), the fungus remained almost unchanged, with a concentration of $5.10 \log _{10} \mathrm{CFU} / \mathrm{mL}$. The C. cladosporioides concentration decreased to $5.09 \log _{10} \mathrm{CFU} / \mathrm{mL}$ after washing with $5 \mathrm{~mL}$ of SAEW $20 \mathrm{mg} / \mathrm{L}$. After washing the agar plate with $5 \mathrm{~mL}$ of SAEW $40 \mathrm{mg} / \mathrm{L}$, a dramatic decrease in the fungal population, to $3.42 \log _{10} \mathrm{CFU} / \mathrm{mL}$, was observed. This indicates that there was a more than 2 orders of magnitude decrease $\left(2.16 \log _{10} \mathrm{CFU} / \mathrm{mL}\right)$ and thus, $40 \mathrm{mg} / \mathrm{L}$ of SAEW 40 might be effective in preventing the growth of black mold in households.

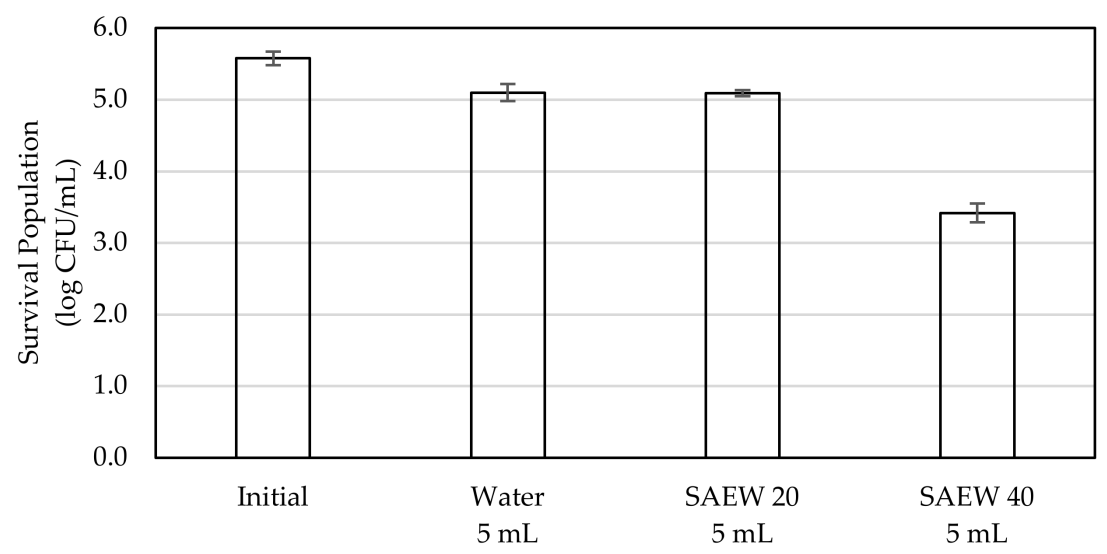

Figure 4. Survival population of Cladosporium cladosporioides after SAEW treatment.

Mesh experiments with black mold showed that washing the black mold impregnated mesh 5 times with SAEW $40 \mathrm{mg} / \mathrm{L}$ and leaving it overnight under agitation was enough to completely remove the black mold (Figure 5). No change was observed after the same treatment with water (experimental control). Mesh experiments using C. cladosporioides may suggest that SAEW not only prevents black mold formation but can also be used to 
remove black mold afterwards. However, due to the low concentration of SAEW (40 mg/L or $0.004 \%$ ), washing several times becomes crucial.

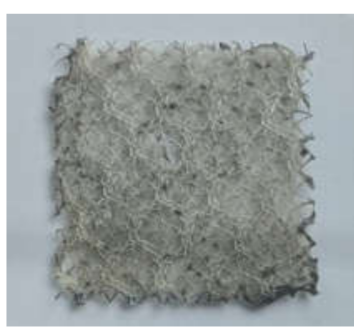

(a) Before

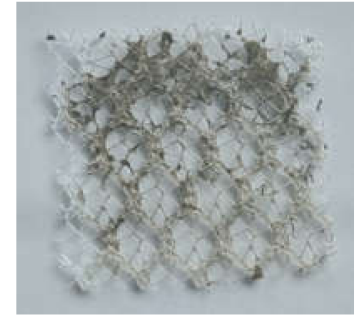

(b) Water washing

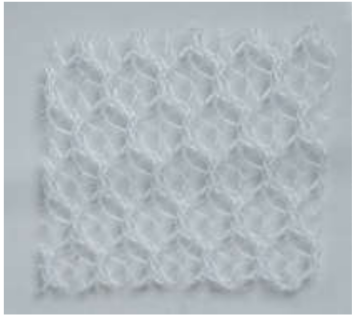

(c) SAEW washing

Figure 5. Mesh before and after washing with water and SAEW. (a) Before, (b) after water washing, (c) after SAEW washing.

\section{Discussion}

The active component in SAEW is hypochlorous acid $(\mathrm{HOCl})$, which is a strong oxidizing agent. In aqueous solutions, chlorine exists in three forms: $\mathrm{Cl}_{2}, \mathrm{HOCl}$ and $\mathrm{ClO}^{-}$. Chlorine slightly dissolves in water to form $\mathrm{HOCl}$, which partially dissociates to form $\mathrm{ClO}^{-}$. The equilibrium between $\mathrm{HOCl}$ and $\mathrm{ClO}^{-}$is $\mathrm{pH}$-dependent. At $\mathrm{pH}$ between 4 and 6, $\mathrm{HOCl}$ becomes the predominant species. It is believed that HOCl's germicidal activity is due to its ability to penetrate the microbial cell wall and plasma membrane, causing damage to the DNA and also inhibiting enzyme activity essential for growth [18]. Kiura et al. [19], Nan et al. [20], Ding et al. [21] and Kim et al. [22] reported on the bacterial cellular morphology before and after treatment with solutions containing free chlorine by transmission electron microscopy. They concluded that bacterial cells were damaged, destroyed or deformed due to exposure to SAEW with free chlorine concentrations between 10 to $60 \mathrm{mg} / \mathrm{L}$.

Due to the SARS-CoV-2 pandemic, people spend more time indoors. Fungal and bacterial communities on household surfaces are diverse in composition, and they can cause several diseases such as asthma or allergies. Regularly cleaning or washing surfaces with SAEW may be a safe way to prevent these microorganisms from spreading inside the home. Results presented in this research suggest that SAEW can remove pink-colored biofilm and black mold. From the overall results of this research, we can say that SAEW has a low $\mathrm{HOCl}$ concentration, and thus, repeated application of this substance is suggested, especially when disinfecting surfaces. Parish, et al. [3] reported that chlorine aqueous solutions are commonly used in a concentration range of between 50 and $200 \mathrm{mg} / \mathrm{L}$, with a contact time of 1 to 2 min to sanitize surfaces or equipment in contact with food. In this research, we set the contact time to $3 \mathrm{~min}$, which is long enough to secure SAEW's action. SAEW can easily react with organic matter and, therefore, may react with organic matter such as dust before it can reach the target microorganism. Therefore, it is recommended to clean target surfaces or remove organic matter from them before SAEW application to maximize its disinfection potential. According to Takehara and Fukuzaki [23], the maximum decrease in available chlorine concentration due to the presence of organic matter was observed at $\mathrm{pH}$ 9.5, whereas the minimum was reported at $\mathrm{pH} 4.5$. Considering that the $\mathrm{pH}$ of $\mathrm{SAEW}$ is between 4.5 to 6 , it can be said that the presence of organic matter has a smaller impact when compared with sodium hypochlorite $\left(\mathrm{ClO}^{-}\right)$, which has $\mathrm{pH}$ of around 8.5 to 10 . Moreover, Takeda et al. [24] reported that $34 \mathrm{mg} / \mathrm{L}$ of SAEW was effective in inactivating SARS-CoV-2 even in the presence of high concentrations of organic substances.

The application of SAEW is diverse; it can inactivate bacteria and viruses and be used either as solution or spray. This study constitutes a first approach to evaluate new applications of SAEW in dwellings such as for preventing or reducing common fungi and bacterial contamination. High concentration disinfectants tend to be effective, but also produce harm. Conversely, safe disinfectants are commonly less effective. In this regard, SAEW constitutes a possible alternative. The safety of SAEW in Japan has been extensively 
studied by the Food Safety Commission, the Ministry of Agriculture, Forestry and Fisheries, the Ministry of Environment, and the Ministry of Health, Labor and Welfare. No risk of harm to humans, animals or plants has been found. Considering that SAEW has a low $\mathrm{HOCl}$ concentration (lower than $80 \mathrm{mg} / \mathrm{L}$ ) but rapid action, it is highly recommended that it be used under running water conditions [24] such as when washing bath tubs or kitchen sinks or when used for hand washing. Further studies can be performed with several surfaces and more species to better understand SAEW's application range.

\section{Conclusions}

Results obtained in this study demonstrated that SAEW effectively reduced colonies of Methylobacterium mesophilicum, Rhodotorula mucilaginosa and Cladosporium cladosporioides. A maximum reduction of $M$. mesophilicum was observed after washing the plate 5 times with $10 \mathrm{~mL}$ of SAEW $40 \mathrm{mg} / \mathrm{L}$. For R. mucilaginosa and C. cladosporioides, greater than 2 orders of magnitude decreases in their populations were observed. Overall results indicated that SAEW was particularly effective against the $R$. mucilaginosa and C. cladosporioides species commonly found in Japanese households. Mesh experiments showed that SAEW can remove black mold.

SAEW is a highly safe disinfectant due to its low $\mathrm{HOCl}$ concentration $(0.008 \%$ of $\mathrm{HOCl}$ at most and $99.992 \%$ water). It can be effective even at low concentrations, which makes it suitable for surfaces and household disinfection, especially when used under running water conditions.

Author Contributions: Conceptualization, A.N. and M.K.; methodology, A.N. and M.K.; validation, A.N., K.N. and M.K.; formal analysis, A.N., K.N. and M.K.; investigation, A.N., K.N. and M.K.; resources, M.K.; data curation, A.N., K.N. and M.K.; writing-original draft preparation, A.N. and M.K.; writing—review and editing, A.N. and M.K.; visualization, A.N. and M.K.; supervision, M.K.; project administration, M.K.; funding acquisition, M.K. All authors have read and agreed to the published version of the manuscript.

Funding: This research received no external funding.

Institutional Review Board Statement: Not applicable.

Informed Consent Statement: Not applicable.

Data Availability Statement: Data is contained within the article.

Acknowledgments: We would like to thank Hokuetsu Co., Ltd. for the technical assistance. The authors would also like to thank the anonymous reviewers for their valuable comments.

Conflicts of Interest: This work was conducted in collaboration with the Research Department of Toyotomi Co. Ltd. This commercial affiliation does not alter our adherence to all MDPI Applied Microbiology policies.

\section{References}

1. Block, M.S.; Rowan, B.G. Hypochlorous acid-A review. J. Oral Maxillofac. Surg. 2020, 78, 1461-1466. [CrossRef]

2. Folkes, L.K.; Candeias, L.P.; Wardman, P. Kinetics and Mechanisms of Hypochlorous Acid Reactions. Arch. Biochem. Biophys. 1995, 323, 120-126. [CrossRef]

3. Parish, M.; Beuchat, L.; Suslow, T.; Harris, L.; Garrett, E.; Farber, J.; Busta, F. Methods to Reduce/Eliminate Pathogens from Fresh and Fresh-Cut Produce. Compr. Rev. Food Sci. Food Saf. 2003, 2, 161-173. [CrossRef]

4. Mitsuboshi, S.; Yamaguchi, R.; Uchida, H.; Kamoshida, S.; Hashi, H. Inappropriate sales of hypochlorous acid solution in Japan: An online investigation. Infect. Control. Hosp. Epidemiol. 2020, 42, 1297-1299. [CrossRef]

5. Naka, A.; Yakubo, M.; Nakamura, K.; Kurahashi, M. Effectiveness of slightly acidic electrolyzed water on bacteria reduction: In vitro and spray evaluation. PeerJ 2020, 8, e8593. [CrossRef]

6. Hao, X.X.; Li, B.M.; Wang, C.Y.; Zhang, Q.; Cao, W. Application of slightly acidic electrolyzed water for inactivating microbes in a layer breeding house. Poult. Sci. 2013, 92, 2560-2566. [CrossRef] [PubMed]

7. Hao, X.; Cao, W.; Li, B.; Zhang, Q.; Wang, C.; Ge, L. Slightly acidic electrolyzed water for reducing airborne microorganisms in a layer breeding house. J. Air Waste Manag. Assoc. 2013, 64, 494-500. [CrossRef] [PubMed] 
8. Zheng, W.; Zhao, Y.; Xin, H.; Gates, R.S.; Li, B.; Zhang, Y.; Soupir, M.L. Airborne particulate matter and culturable bacteria reduction from spraying slightly acidic electrolyzed water in an experimental aviary laying-hen housing chamber. Trans. ASABE 2014, 57, 229-236.

9. Kurahashi, M.; Ito, T.; Naka, A. Spatial disinfection potential of slightly acidic electrolyzed water. PLoS ONE 2021, 16, e0253595. [CrossRef] [PubMed]

10. Ara, K.; Aihara, M.; Ojima, M.; Toshima, Y.; Yabune, C.; Tokuda, H.; Kawai, S.; Ueda, N.; Tanaka, T.; Akiyama, K.; et al. Survey of fungal contamination in ordinary houses in Japan. Allergol. Int. 2004, 53, 369-377. [CrossRef]

11. Moriyama, Y.; Nawata, N.; Tsuda, T.; Nitta, M. Occurrence of moulds in Japanese bathrooms. Int. Biodeterior. Biodegrad. 1992, 30 , 47-55. [CrossRef]

12. Baxi, S.N.; Portnoy, J.M.; Larenas-Linnemann, D.; Phipatanakul, W.; Barnes, C.; Baxi, S.; Grimes, C.; Horner, W.E.; Kennedy, K.; Larenas-Linnemann, D. Exposure and health effects of fungi on humans. J. Allergy Clin. Immunol. Pract. 2016, 4, 396-404. [CrossRef]

13. Hamada, N.; Abe, N. Physiological characteristics of 13 common fungal species in bathrooms. Mycoscience 2009, 50, 421-429. [CrossRef]

14. Adams, R.I.; Miletto, M.; Taylor, J.W.; Bruns, T.D. The Diversity and Distribution of Fungi on Residential Surfaces. PLoS ONE 2013, 8, e78866. [CrossRef]

15. Vesper, S.; Wymer, L.; Meklin, T.; Varma, M.; Stott, R.; Richardson, M.; Haugland, R. Comparison of populations of mould species in homes in the UK and USA using mould-specific quantitative PCR. Lett. Appl. Microbiol. 2005, 41, 367-373. [CrossRef]

16. Ihara, N.; Sakamoto, J.; Yoshida, M.; Tsuchido, T. Killing effect of peppermint vapor against pink-slime forming microorganisms. Biocontrol Sci. 2015, 20, 91-97. [CrossRef] [PubMed]

17. Hiraishi, A.; Furuhata, K.; Matsumoto, A.; A Koike, K.; Fukuyama, M.; Tabuchi, K. Phenotypic and genetic diversity of chlorine-resistant Methylobacterium strains isolated from various environments. Appl. Environ. Microbiol. 1995, 61, 2099-2107. [CrossRef]

18. Fukuzaki, S. Mechanisms of Actions of Sodium Hypochlorite in Cleaning and Disinfection Processes. Biocontrol Sci. 2006, 11, 147-157. [CrossRef]

19. Kiura, H.; Sano, K.; Morimatsu, S.; Nakano, T.; Morita, C.; Yamaguchi, M.; Maeda, T.; Katsuoka, Y. Bactericidal activity of electrolyzed acid water from solution containing sodium chloride at low concentration, in comparison with that at high concentration. J. Microbiol. Methods 2002, 49, 285-293. [CrossRef]

20. Nan, S.; Li, Y.; Li, B.; Wang, C.; Cui, X.; Cao, W. Effect of Slightly Acidic Electrolyzed Water for Inactivating Escherichia coli O157:H7 and Staphylococcus aureus Analyzed by Transmission Electron Microscopy. J. Food Prot. 2010, 73, 2211-2216. [CrossRef]

21. Ding, T.; Xuan, X.-T.; Li, J.; Chen, S.-G.; Liu, D.-H.; Ye, X.-Q.; Shi, J.; Xue, S.J. Disinfection efficacy and mechanism of slightly acidic electrolyzed water on Staphylococcus aureus in pure culture. Food Control 2016, 60, 505-510. [CrossRef]

22. Kim, H.-J.; Tango, C.N.; Chelliah, R.; Oh, D.-H. Sanitization Efficacy of Slightly Acidic Electrolyzed Water against pure cultures of Escherichia coli, Salmonella enterica, Typhimurium, Staphylococcus aureus and Bacillus cereus spores, in Comparison with Different Water Hardness. Sci. Rep. 2019, 9, 4348. [CrossRef] [PubMed]

23. Takehara, A.; Fukuzaki, S. Relationship between the $\mathrm{pH}$ and decrease in available chlorine of sodium hypochlorite in the presence of organic compounds or during freezing treatment. Rep. Ind. Technol. Ctr. Okayama Pref. 2006, 32, 10-13.

24. Takeda, Y.; Jamsransuren, D.; Makita, Y.; Kaneko, A.; Matsuda, S.; Ogawa, H.; Oh, H. Inactivation Activities of Ozonated Water, Slightly Acidic Electrolyzed Water and Ethanol against SARS-CoV-2. Molecules 2021, 26, 5465. [CrossRef] [PubMed] 